and interstitial fibrosis. ${ }^{719-21}$ The changes seem to be more severe in bilateral cryptorchidism. ${ }^{7}$ In unilateral cryptorchidism the scrotal testis may show similar histological changes. ${ }^{6}{ }^{7}$ The common finding of raised gonadotrophin levels indicates that cryptorchidism is generally a primary testicular disease. Conversely, the high incidence of cryptorchidism in those with gonadotrophin deficiency ${ }^{22}$ and our patients with low peak LH values suggest that in a minority the undescended testis may also be a secondary manifestation of hypothalamo-pituitary dysfunction.

This work was supported by the Schweizerischer Nationalfonds zur Förderung der wissenschaftlichen Forschung, grants No KF 1, 3.422.074, 3.405.074.

\section{References}

${ }^{1}$ Hansen, T S, Proceedings of the Royal Society of Medicine, 1959, 42, 645.

2 Scott, L S, Proceedings of the Royal Society of Medicine, 1962, 55, 1047.

${ }^{3}$ Bergstrand, C G, and Qvist, O, in Long-term Observations of Chronic Diseases, ed F Linneweh, p 254. Berlin, Springer, 1960.
${ }^{4}$ Maier, W, and Spann, W, Deutsche medizinische Wochenschrift, 1962, 87, 1697.

5 Albescú, J C, Bergadá, C, and Cullen, M, Fertility and Sterility, 1971, 22, 829.

${ }^{6}$ Hecker, W C, and Hienz, H A, fournal of Pediatric Surgery, 1967, $2,513$.

' Salle, B, Hedinger, C, and Nicole, R, Acta Endocrinologica (København), $1968,58,67$.

Zachmann, M, et al, Helvetica Paediatrica Acta, 1974, 29, 61.

9 MacCollum, D W, Archives of Surgery, 1953, 31, 290.

${ }^{10}$ Brunet, J, De Mowbray, R R, and Bishop, P M F, British Medical fournal, 1958, 1, 1367.

${ }^{11}$ Hortling, H, et al, fournal of Clinical Endocrinology, 1967, 27, 120

${ }^{12}$ Bramble, F J, et al, Lancet, 1974, 2, 311.

${ }^{13}$ Richter, W, et al, Klinische Wochenschrift, 1976, 54, 467.

${ }^{14}$ Ludwig, G, and Potempa, J, Deutsch medizinische Wochenschrift, 1975, 100,680 .

${ }^{15}$ Bramble, F J, et al, Clinical Endocrinology, 1975, 4, 443.

${ }^{16}$ Epstein, M T, Atkinson, P M, and Rippon, A E, fournal of Endocrinology, 1975, 65, 11 P.

${ }^{17}$ Koch, H, et al, Deutsche medizinische Wochenschrift, 1975, 100, 683.

${ }_{18}$ Canlorbe, P, et al, Archives Francaises de Pédiatrie, 1974, 31, 145.

19 Sohval, A R, American fournal of Medicine, 1954, 16, 346.

${ }^{20}$ Mancini, R E, et al, fournal of Clinical Endocrinology, 1965, 25, 927.

${ }^{21}$ Dougall, A J, Maclean, N, and Wilkinson, A W, Lancet, 1974, 1, 771.

${ }^{22}$ Santen, R J, and Paulsen, C A, fournal of Clinical Endocrinology, 1973, 36, 47.

\title{
Weak autoantibody reactions to antigens other than sperm after vasectomy
}

\author{
J D MATHEWS， D C G SKEGG， M P VESSEY， M KONICE， E J HOLBOROW， J GUILLEBAUD
}

British Medical fournal, 1976, 2, 1359-1360

\section{Summary}

Autoantibody activity against various antigens was measured by indirect immunofluorescence in 97 men about to undergo vasecto my and 170 men who had undergone the operation up to six years earlier. There was a significantly higher prevalence of weakly positive autoantibody reactions among those who had undergone vasectomy. There was, however, no evidence that vasectomy could induce stronger autoantibody reactions such as those associated with autoimmune disease.

\section{Introduction}

Antibodies to sperm are often produced after vasectomy, ${ }^{1-3}$ although there is no evidence that they affect health. ${ }^{1}$ We

Department of the Regius Professor of Medicine, University of Oxford, Oxford

J D MATHEWS, MD, FRACP, research fellow (present address: University Department of Medicine, Royal Melbourne Hospital, 3050 Victoria, Australia)

D C G SKEGG, BMEDSC, MB, lecturer in epidemiology

Department of Social and Community Medicine, University of Oxford, Oxford

$M$ P VESSEY, MD, FFCM, professor

MRC Rheumatism Unit, Canadian Red Cross Hospital, Taplow, Berks

$M$ KONICE, MD, research fellow

E J HOLBOROW, MD, MRCPATH, director

Nuffield Department of Obstetrics and Gynaecology, University of Oxford, Oxford

J GUILLEBAUD, FRCS ED, MRCOG, research fellow conducted a study to determine whether the prevalence of autoantibodies to antigens other than sperm is also increased after vasectomy.

\section{Methods}

As previously reported, ${ }^{4} 288$ men were examined: 100 before vasectomy and 188 at varying intervals up to six years after the operation. Blood was taken and serum stored at $-20^{\circ} \mathrm{C}$. Samples were available from 97 men in the prevasectomy group and 170 men after operation.

Autoantibody activity was measured by indirect immunofluorescence using compound tissue blocks of rat liver, kidney, and stomach as substrates. ${ }^{5}$ Coded sera were assayed blind at a dilution of $1 / 10$ using polyspecific fluorescent antiglobulin reagents. The strength of immunofluorescence was graded from 0 (negative) to 4 (strongly positive) for each of the following antigens: nuclei in liver, tubules and brush border in kidney, and parietal cells in stomach. Smooth muscle antibody and reticulin antibody (including atypical reticulin patterns) were graded according to established criteria..$^{5-7}$ Mitochondrial, bile duct, adventitial, and Kupffer cell staining were graded as 0 (negative) or 1 (positive).

\section{Results}

At least one autoantibody reaction was observed in 127 of the 170 men who had undergone vasectomy $(74.7 \%)$ compared with 58 of the 97 men seen before operation $(59.8 \%)$. This difference was statistically significant $\left(\chi_{1}^{2}=5.77 ; \mathrm{P}<0.02\right)$. Men who had had vasectomies also tended to have more positive autoantibody reactions (table I).

TABLE I-Proportions of men with and without vasectomies who had different numbers of positive autoantibody reactions. Results are numbers (and percentages)

\begin{tabular}{|c|c|c|c|c|c|}
\hline No of positive reactions: & 0 & 1 & 2 & 3 & $\geqslant 4$ \\
\hline $\begin{array}{l}\text { Before vasectomy }(n=97) \\
\text { After vasectomy }(n=170)\end{array}$ & $\begin{array}{l}39(40 \cdot 2) \\
43(25 \cdot 3)\end{array}$ & $\left|\begin{array}{l}27(27 \cdot 8) \\
47(27 \cdot 6)\end{array}\right|$ & $\begin{array}{l}18(18.6) \\
44(25.9)\end{array}$ & $\begin{array}{c}9(9 \cdot 3) \\
29(17 \cdot 1)\end{array}$ & $\begin{array}{l}4(4 \cdot 1) \\
7(4 \cdot 1)\end{array}$ \\
\hline
\end{tabular}

$\chi_{1}^{2}$ for trend $=6.44 ; P<0.02$ 
TABLE II-Percentages of men with positive autoantibody reactions (grades 1-4) according to time since vasectomy. Percentages of men with reactions of grade 3 or more are given in parentheses

\begin{tabular}{|c|c|c|c|c|c|c|}
\hline \multirow{2}{*}{ Autoantibody specificity } & \multirow{2}{*}{$\begin{array}{l}\text { Prevasectomy } \\
\text { group }\end{array}$} & \multicolumn{5}{|c|}{ Postvasectomy groups. Time since operation (years) } \\
\hline & & $<1$ & $1-2$ & $2-4$ & $\geqslant 5$ & All times \\
\hline $\begin{array}{l}\text { Smooth muscle } \\
\text { Nuclei } \\
\text { Parietal cells } \\
\text { Reticulin } \\
\text { Tubules } \\
\text { Brush border } \\
\text { Mitochondria } \\
\text { Others } \dagger\end{array}$ & $\begin{array}{c}14 \cdot 4(4 \cdot 1) \\
14 \cdot 4(5 \cdot 2) \\
27 \cdot 8(9 \cdot 3) \\
1 \cdot 0(0) \\
4 \cdot 2(2 \cdot 1) \\
32 \cdot 0(1 \cdot 0) \\
1.0 \\
14 \cdot 4\end{array}$ & $\begin{array}{c}25 \cdot 9(7 \cdot 4) \\
11 \cdot 1(0) \\
33 \cdot 3(7 \cdot 4) \\
7 \cdot 4(0) \\
3 \cdot 7(0) \\
37 \cdot 0(0) \\
0 \\
22 \cdot 2\end{array}$ & $\begin{array}{c}29.1(7.3) \\
23.6(5.4) \\
36.4(5.5) \\
3.6(0) \\
7.2(1.8) \\
23.6(0) \\
1.8 \\
16.4\end{array}$ & $\begin{array}{c}18 \cdot 6(4 \cdot 7) \\
23 \cdot 3(7 \cdot 0) \\
32 \cdot 6(11 \cdot 6) \\
7 \cdot 0(0) \\
7 \cdot 0(0) \\
34 \cdot 9(2 \cdot 3) \\
2 \cdot 3 \\
25 \cdot 5\end{array}$ & $\begin{array}{c}11 \cdot 1(0) \\
8 \cdot 9(0) \\
42 \cdot 2(4 \cdot 4) \\
4 \cdot 4(2 \cdot 2) \\
8.8(2 \cdot 2) \\
53 \cdot 3(2 \cdot 2) \\
2 \cdot 2 \\
20 \cdot 0\end{array}$ & $\begin{aligned} 21.2(4 \cdot 7) \\
18 \cdot 2(3.5) \\
36 \cdot 5(7 \cdot 1) \\
5.3(0 \cdot 6) \\
7.6(1 \cdot 2) \\
30.6(1.2) \\
1.8 \\
20.6\end{aligned}$ \\
\hline Any autoantibody & $59 \cdot 8$ & $66 \cdot 7$ & $72 \cdot 7$ & $72 \cdot 1$ & $84 \cdot 4$ & $\mathbf{7 4 \cdot 7}$ \\
\hline No of men tested & 97 & 27 & 55 & 43 & 45 & 170 \\
\hline
\end{tabular}

$†$ †ile duct, adventitial, or Kupffer cell staining.

The percentages of men with positive reactions to each antigen are shown in table II. Those who had had vasectomies were divided according to the time that had elapsed since vasectomy; these groups have been described elsewhere. ${ }^{4}$ There was a significant tendency for the proportion of men with at least one autoantibody to increase with time after the operation $\left(\chi_{1}^{2}\right.$ for trend $\left.=8.91 ; \mathrm{P}<0.01\right)$. Although the prevalence of all but one of the autoantibodies was higher after operation, the difference was not statistically significant for any individual reaction. When weak reactions (grades 1 and 2 ) were disregarded, as is commonly done, the prevalence of several autoantibodies was not higher after vasectomy.

The increased prevalence of weak autoantibody reactions in the postoperative groups of men could not be accounted for by differences in age, smoking habits, or the use of drugs. Nor was the distribution of autoantibodies after operation related to the surgical technique recorded for individual patients. It is interesting, however, that two of the three men who were known to have developed a significant wound infection after vasectomy were found to have three or more autoantibody reactions.

\section{Discussion}

Our results suggest that men who have undergone vasectomy may have more weak autoantibody reactions to a variety of antigens than other men. Nevertheless, the results need to be interpreted with caution. Firstly, some of the reactions may have been due to heteroantibody ${ }^{8}$ rather than autoantibody activity. Secondly, the differences observed were small and not significant for any individual reaction. Thirdly, the autoantibody reactions were weak reactions which are common in normal people. Possibly changes in the prevalence of such reactions might be a result of any operative procedure in which tissue is destroyed rather than a specific effect of vasectomy.
Research on the immunological effects of vasectomy has largely been concerned with the development of antibodies to sperm. Crewe et al, ${ }^{9}$ however, measured several autoantibodies in serum taken from 346 volunteers before and six months after vasectomy. They concluded that there was no significant increase in the occurrence of autoantibodies after vasectomy.

It must be emphasised that there is no evidence in our data of induction of strong autoantibody reactions (such as are associated with autoimmune disease). We found no association between the presence of weak autoantibodies and the development of any undesirable consequences of vasectomy.

We thank Drs R Glass, D Hunter, L J Kinlen, J I Mann, and G K Wilcock for helping with some of the interviews. Professor Sir Richard Doll and Dr K McPherson gave valuable advice.

\section{References}

1 Wortman, J, Population Reports, Series D, p 25. Washington, George Washington University Medical Centre, 1975.

2 Shulman, S, et al, Contraception, 1972, 5, 269.

3 Alexander, N J, Wilson, B J, and Patterson, G D, Fertility and Sterility, $1974,25,149$.

4 Skegg, D C G, et al, British Medical fournal, 1976, 1, 621.

5 Johnson, G D, and Holborow, E J, in Handbook of Experimental Immunology, ed D M Weir, chapter 18. Oxford, Blackwell, 1973.

Seah, P P, et al, Lancet, 1971, 1, 834.

7 Whitehouse, J M A, and Holborow, E J, British Medical fournal, 1971, 4, 511 .

${ }^{8}$ Muller, H K, McGiven, A R, and Nairn, R C, fournal of Clinical Pathology, 1971, 24, 13.

- Crewe, P, et al, Clinical and Experimental Immunology, 1976, 24, 368.

\section{SHORT REPORTS}

\section{Homozygous sickle-cell disease in a Punjabi Moslem boy}

Sickle-cell trait was first noted among aborigines in India in $1952 .{ }^{1}$ Since then it has been recorded in various parts of India. ${ }^{2}$ Homozygous sickle-cell disease, however, has not previously been reported either in natives of the Punjab or in Punjabi Moslems. We report such a case.

\section{Case report}

A 15-month-old Punjabi Moslem boy was first seen because of fever, diarrhoea, respiratory distress, and abnormal sensory responses. His milestones were delayed. He was pale, underweight, and undernourished. Spleen and liver were just palpable, but there was no jaundice, clubbing, or peripheral oedema. Crepitations and bronchial breathing were heard at the base of the left lung. There was generalised hypotonia and hyporeflexia, but no signs of meningeal irritation were present. Blood culture was sterile. Cerebrospinal fluid was normal.

Results of haematological investigations were: haemoglobin $4.6 \mathrm{~g} / \mathrm{dl}$; packed cell volume $0.17(17 \%)$; leucocytes $18 \times 10^{9} / 1\left(18000 / \mathrm{mm}^{3}\right)$ neutrophils $90 \%$, lymphocytes $10 \%$; platelets $176 \times 10^{9} / 1\left(176000 / \mathrm{mm}^{3}\right)$; and reticulocytes $6 \%$. Peripheral blood smear showed pronounced anisocytosis and poikilocytosis; sickling of about $50 \%$ of the red cells; fragmented, polychromatic, and nucleated red cells; and a shift to the left in leucocytes. The provisional diagnosis was sickle-cell anaemia in crisis with left lowerlobe pneumonia. Detailed haematological findings in the patient and his parents are given in the table.

The parents refused investigation of the patient's two brothers and two sisters, though apart from the younger girl, who looked "pale," all were said to be normal. There was no history of consanguinity or of unexplained deaths in the family. 